\title{
Biofuel Combustion Emissions - Chemical and Physical Smoke Properties
}

\author{
Chuen-Yu Chan ${ }^{1}$, Guenter Engling ${ }^{2}$, Xuefang Sang ${ }^{1}$ and Ting Zhang ${ }^{1}$ \\ ${ }^{1}$ School of Environmental Science and Engineering, Sun Yat-Sen University, Guangzhou, \\ 2Department of Biomedical Engineering and Environmental Sciences, National Tsing Hua \\ University, Hsinchu \\ ${ }^{1}$ China \\ ${ }^{2}$ Taiwan
}

\section{Introduction}

Biofuels have recently gained much attention, mainly as alternative fuels for applications in energy generation and transportation. The utilization of biofuels in such controlled combustion processes has the great benefit of not further depleting the limited resources of fossil fuels, yet it is associated with emissions of greenhouse gases and smoke particles similar to traditional combustion processes, i.e., those of fossil fuels. On the other hand, a vast amount of biofuels is subject to combustion in small-scale processes, such as for heating and cooking in residential dwellings, as well as in agricultural operations, such as for crop residue removal and land clearing. In addition, large amounts of biomass are consumed annually during forest and savanna fires in many parts of the world. These types of burning processes are typically uncontrolled and unregulated. Consequently, the emissions from such processes may be substantially larger compared to industrial-type operations. Aside from direct effects on human health, especially due to a sizeable fraction of the smoke emissions remaining inside residential homes, the smoke particles and gases released from uncontrolled biofuel combustion impose significant effects on regional and global climate. Estimates have shown the majority of carbonaceous airborne particulate matter to be derived from the combustion of biofuels and biomass. The resulting "clouds" of carbonaceous aerosol particles nowadays span vast areas across the Globe. Aside from the negative health impacts and influence on global climate, these smoke particles affect biogeochemical cycles and regional air quality, which is also associated with severe economic impacts.

Whereas emissions from industrial operations and traffic have been fairly well characterized, smoke released during combustion of biofuels is poorly understood in terms of its chemical composition and physical properties. Biofuel combustion generates smoke particles which are predominantly of carbonaceous nature, consisting of an organic carbon (OC) and an elemental carbon (EC) fraction, the latter of which is at times mistakenly referred to as black carbon (BC) or soot. While the OC and EC fractions can be quantified by various methods, there is a large gap in our knowledge regarding the specific composition of OC in biofuel smoke particles. In fact, OC is composed of thousands of individual organic compounds with a wide range of chemical and physical properties. Recent advances in the 
speciation of the OC fraction in smoke aerosol generated from biofuel combustion provide some new insights into the chemical and physical characteristics of such particles. For instance, it is now understood that biomass smoke particles contain a sizeable portion of higher molecular weight substances as well as polar organic compounds. However, much effort is still needed to better characterize emissions from biofuel combustion, which has to include source and near-source emissions measurements as well as better characterization of ambient aerosol influenced by biofuel/biomass smoke.

This chapter will give an overview of the current state of knowledge regarding the chemical and physical properties of smoke aerosol released from biofuel combustion, by providing selected key references, and point out future research needs and directions.

\section{Biofuel usage in Asia and China}

In Asia, biofuel emissions are very substantial and have significant influence on regional air quality. Streets et al. (2003) estimated that the major biofuel emissions in Asia arose from the combustion of woods, animal waste (dung) and agricultural waste, and the high biofuel emission regions were mainly located in central and East China, Southeast Asia, and South Asia by spatial and rural population allocation. The average annual biofuel consumption in Asia was estimated to be $730 \mathrm{Tg}$ from both anthropogenic and natural sources, with 45, 34 and $20 \%$ accounted for by forest burning, crop residue open burning and grassland/savanna burning, respectively. When allocated to countries, it was found that China contributed 25\%, India 18\%, Indonesia 13\%, and Myanmar 8\% of the total consumption. Regionally, forest fires in Southeast Asia dominated.

Tropical Southeast Asia is an active biofuel emission region as a result of increasing deforestation and agricultural activities (Stott, 1988; Christopher and Kimberly, 1996; Dwyer et al., 1998), including East-Central India and the region comprised by Thailand, Burma, Laos, Cambodia and Vietnam (Christopher and Kimberly, 1996). March and April constitute the intensive burning season in this region (Stott, 1988). The intensive fire activity resulting from burning of agricultural waste and shifting cultivation is clearly reflected by the fire hot spots derived from the Along Track Scanning Radiometer (ATSR) on board of a European Space Agency (ESA) satellite (Figure 1); these fires usually reach their full strength in March or April (Figure 2). The amount of biofuels burned in all tropical Asia is very large, which was estimated at about one-half of the amount burned in tropical America, and about onethird of the amount burned in tropical Africa (Liu et al., 1999).

China has a large rural population whose major energy source has been biofuels (crop residues, fuel woods, etc.) for the last several decades. It is not uncommon to see burning of wood and crop residues in kitchens and stoves in the countryside, and even in the surrounding regions of wealthy areas, such as Guangdong Province and Beijing. In addition, biofuel burning is often used as a convenient way of clearing vegetated areas in China (Figure 3). Based on the crop output data from 2001 to 2005, Yang et al. (2008) estimated that the generated annual average amount of crop residue was $3.04 \times 10^{6} t$, and about $43 \%$ of this was burned in the field. According to the stastics of Guangdong Province, the annual consumption of fuel wood in Guangdong Province is about 5.13-6.00 Tg, and $30 \%-40 \%$ of the produced straws is used as biofuel. $\mathrm{PM}_{2.5}$ mass concentrations derived from rice straw combustion can reach as much as $3557 \mathrm{Tg}$. There have been several literature reports of biofuel/biomass burning contributions to ambient air in China (Zhang et al., 2008; Zhang et al., 2010; Sang et al., 2011). 


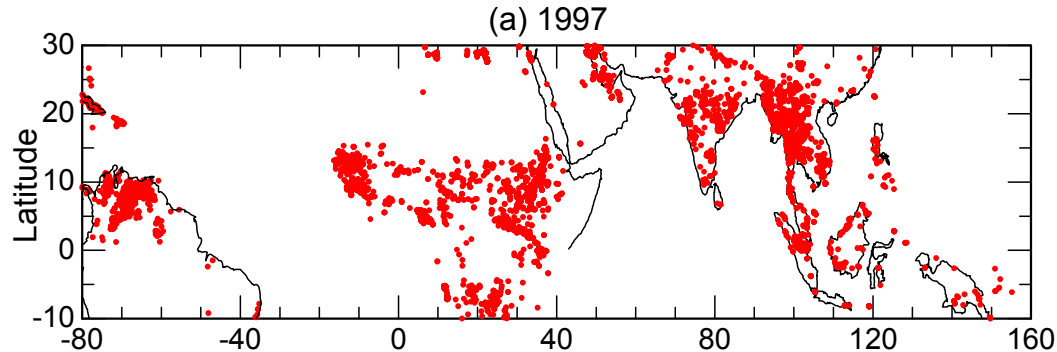

(b) 1998

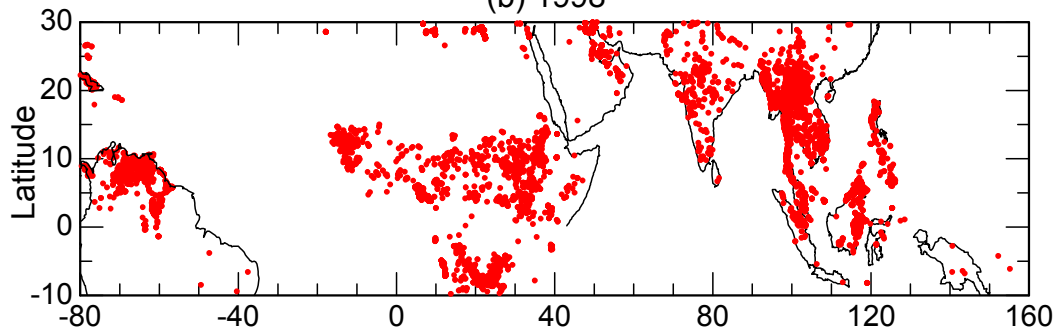

(c) 1999

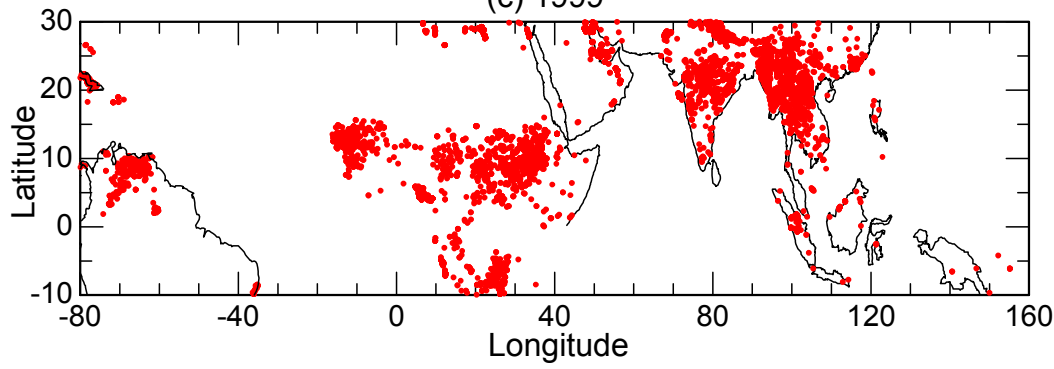

Fig. 1. The geographical distribution of fire hot spots in the tropics derived from ATSR data

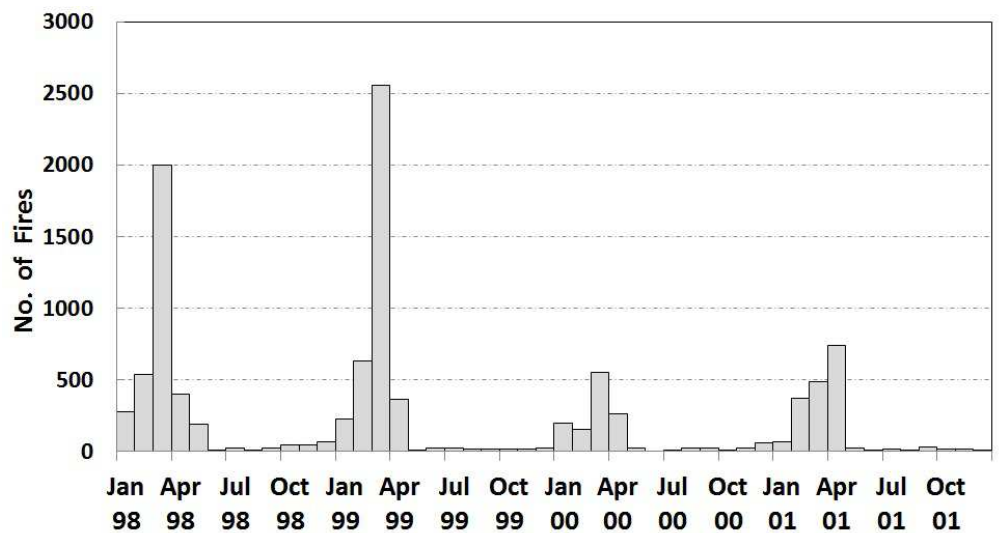

Fig. 2. Monthly variability of fire hot spots in the southeast Asian subcontinent $\left(30^{\circ} \mathrm{N}, 90^{\circ} \mathrm{E}-5^{\circ} \mathrm{N}, 115^{\circ} \mathrm{E}\right)$ 


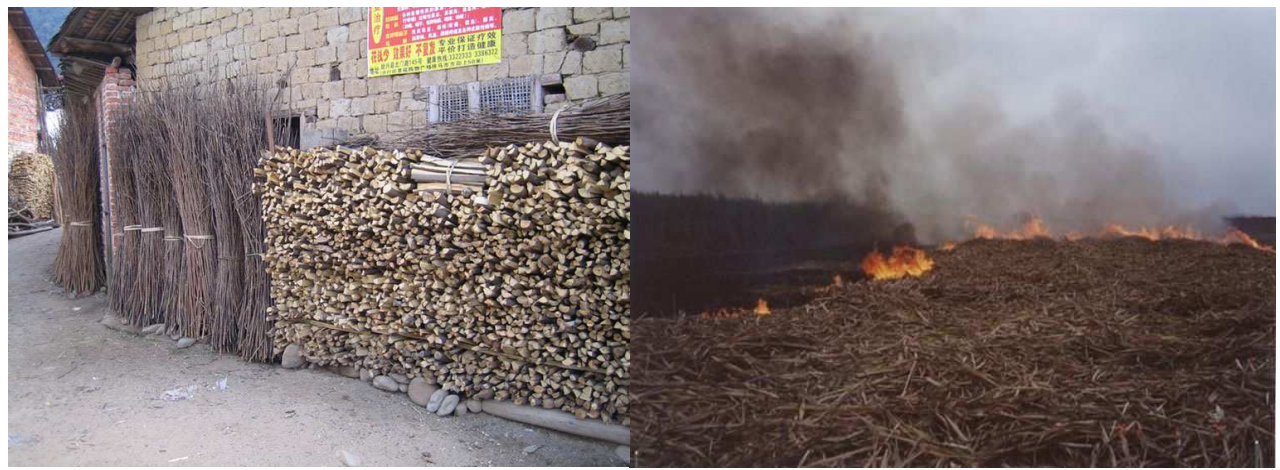

Fig. 3. Photos showing storage of fuel wood in a typical household in a village of south China (left) and burning of crop residues (right) in a sugarcane field of western Guangdong Province

\section{Combustion process}

Biomass/biofuel burning can be divided into four types: forest fires, savanna or grassland fires, burning of crop residues in the field and domestic biofuel combustion. Here we refer to biofuels mainly in respect to biomass burned in domestic stoves and ovens for cooking and heat generation, in contrast to biomass that is openly burned on a larger scale, such as in wildland fires. The main structural components of biomass/biofuels are the biopolymers cellulose (40-50\%), hemicelluloses (20-30\%) and lignins (15-35\%) (Sergejewa, 1959; Petterson, 1984). Cellulose, a linear polymer composed of 7000-12000 D-glucose monomers, is the elementary fibrils and could form larger fiber structures (Sergejewa, 1959). Hemicelluloses, consisting of only about 100-200 sugar monomers, are mixtures of polysaccharides derived from glucose, mannose, galactose, xylose, arabinose, 4-O-methylglucuronic acid (4-OMGA), and galacturonic acid (Sergejewa, 1959; Pharham and Gray, 1984) and are less structured than cellulose molecules. The biofuel combustion processes could be summarized as the heating, flaming and smoldering phases. At the heating stage, biofuels are being hydrolyzed, oxidized, dehydrated and pyrolyzed to form tarry substances, volatiles and highly reactive carbonaceous char (Roberts, 1970; Shafizaden, 1984). When reaching the required temperature of the volatiles and tarry substance, the flaming combustion phase commences, which could provide enough energy for the gasification of the biofuel substrate, propagation of the fire and char formation until the combustible volatile flux drops below the minimum level required for the propagation of flaming combustion. Then the smoldering process starts and is best described as the gradual oxidation of the reactive char (solid phase combustion). Table 1 shows the characteristics of various combustion processes during the different combustion phases. The gas and particle-phase chemical species contained in the smoke released during biomass/biofuel include a large number of compounds with a wide range of chemical and physical properties, depending on biofuel type and combustion conditions. As it is beyond the scope of this chapter to give a comprehensive overview of the chemical smoke constituents, the reader is referred to some key literature (Andreae and Merlet, 2001; Hays et al., 2002; Christian et al., 2003; Akagi et al., 2010), while we will focus the discussion here on source-specific compounds, i.e., molecular tracers for biomass/biofuel combustion. 


\begin{tabular}{|c|c|c|c|}
\hline \multicolumn{2}{|c|}{ Combustion Stage } & Process & Process Characteristics \\
\hline \multirow{4}{*}{$\begin{array}{l}\text { Flamming } \\
\text { Stage }\end{array}$} & \multirow{3}{*}{$\begin{array}{l}\text { Solid } \\
\text { Phase }\end{array}$} & $\begin{array}{l}\text { Drying/Distilling } \\
\text { Process }\end{array}$ & $\begin{array}{l}\text { Water and volatile contents are removed or } \\
\text { diffused into the inner layers of the bulk } \\
\text { material }\end{array}$ \\
\hline & & Pyrolysis Process & $\begin{array}{l}\text { Starts at about } 400 \mathrm{~K} \\
\text { Below } 450 \mathrm{~K} \text { the process is endothermic } \\
\text { Above } 450 \mathrm{~K} \text { the process is exothermic } \\
\text { Dehydrocellulose decompostion takes place }\end{array}$ \\
\hline & & $\begin{array}{l}\text { Glowing } \\
\text { Combustion }\end{array}$ & $\begin{array}{l}\text { Starts at about } 800 \mathrm{~K} \text { if oxygen is present } \\
\text { Resulting in char being oxidized }\end{array}$ \\
\hline & $\begin{array}{l}\text { Gas } \\
\text { Phase }\end{array}$ & The Flame & $\begin{array}{l}\text { The emitted volatiles are converted to } \\
\text { combustion products of low-molecular weight }\end{array}$ \\
\hline \multicolumn{2}{|c|}{ Smoldering Stage } & $\begin{array}{l}\text { Smoldering } \\
\text { Process }\end{array}$ & $\begin{array}{l}\text { A low-temperature process } \\
\text { Takes place at concentrations of oxygen as low } \\
\text { as } 5 \% \\
\text { Can proceed over days under conditions of } \\
\text { high moisture }\end{array}$ \\
\hline
\end{tabular}

Table 1. Different combustion stages and the characteristics of different combustion processes

\section{Molecular tracers for biomass burning processes}

During the combustion, the cellulose molecules decompose by two pathways. When the temperature is $<300$ degrees $C$, biofuels are depolymerized, fragmented and oxidized to char. During the second pathway, i.e. > 300 degrees C, bond cleavage by transglycosylation, fission and disproportionation reactions give rise to the formation of levoglucosan, accompanied by its stereoisomers, mannosan (Man) and galactosan (Gal). (Simoneit et al., 1999; Schmidl et al., 2008b; Engling et al., 2009; Fabbri et al., 2009). Due to reasonable atmospheric stability with no decay over 10 days in acidic conditions, levoglucosan has been widely used as a molecular marker for biomass burning processes (Fraser and Lakshmanan, $2000)$, although it could be oxidized when exposed to gas phase hydroxyl radicals $(\mathrm{OH})$ (Hennigan et al., 2010), nitrate $\left(\mathrm{NO}_{3}\right)$ or sulfate $\left(\mathrm{SO}_{4}\right)$ radicals (Hoffmann et al., 2010). Combustion of other materials (e.g., fossil fuels) or biodegradation and hydrolysis of cellulose does not produce any levoglucosan.

The typical bulk chemical composition of smoke particles derived from agricultural residues/fuels is shown in Figure 4 by the example of rice straw smoke particles. While OC being the predominant species in the carbonaceous fraction, chloride and potassium are the key components in the ionic fraction of smoke aerosol found in source emissions studies. As such, biomass burning plumes are generally characterized by high water-soluble potassium content, specifically enriched in the fine mode. Thus, potassium has also been used as source tracer to estimate the contributions of biomass burning smoke to the ambient aerosol burden (e.g., Duan et al., 2004). However, other sources, such as sea salt, mineral dust and meat cooking, contribute additional potassium to atmospheric PM (Lawson and Winchester, 1979; Morales et al., 1996; Schauer et al., 2002). This may cause a certain bias in the quantitative estimation of contributions from biomass burning emissions when using potassium as source tracer, although a correction for sea-salt contributions is possible. Potassium/levoglucosan ratios which could be utilized for the identification of open/stove 
fires are below 0.2 for wood combustion in fire places and ovens, while they approach 0.5 for open fires (Fine et al., 2001; Fine et al., 2002; Fine et al., 2004a; Puxbaum et al., 2007).

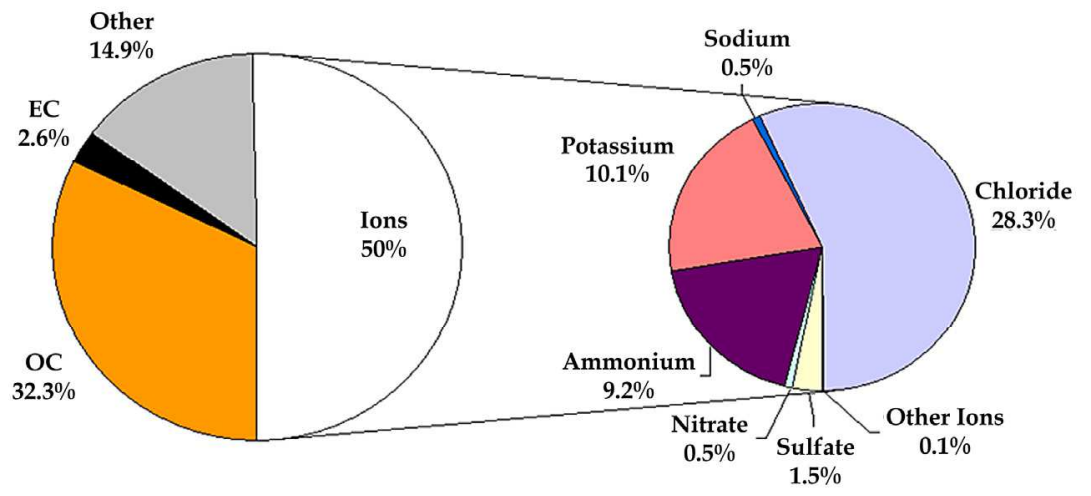

Fig. 4. Typical chemical composition of smoke particles derived from rice straw burning

Table 2 gives a summary of ambient concentrations of levoglucosan, mannosan and galactosan reported for rural, suburban and urban regions around the world. Anhydrosugar concentrations at rural sites have been observed with the highest levels, reaching thousands of $\mathrm{ng} / \mathrm{m}^{3}$, while they were in the hundreds $\mathrm{ng} / \mathrm{m}^{3}$ levels in suburban and urban locations. The variability in these data is mainly influenced by the biofuel usage patterns and potential smoke transport.

\begin{tabular}{|c|c|c|c|c|c|c|}
\hline Location & Season & $\begin{array}{c}\text { Particle } \\
\text { Size }\end{array}$ & $\begin{array}{c}\text { Levoglucosan } \\
\left(\text { ng }^{-3}\right) \\
\text { (Range } \\
\text { (ave)/Ave } \pm \text { S.D.) }\end{array}$ & $\begin{array}{c}\begin{array}{c}\text { Mannosan } \\
\left(\text { ng }^{-3}\right)\end{array} \\
\text { (Range } \\
\text { (ave)/Ave } \pm \text { S.D.) }\end{array}$ & \begin{tabular}{|c}
$\begin{array}{c}\text { Galactosan } \\
\left(\text { ng }^{-3}\right) \\
\text { (Range } \\
\text { (ave)/Ave } \pm \text { S.D. })\end{array}$
\end{tabular} & Reference \\
\hline Rural & Dry & $\mathrm{PM}_{2.5}$ & $1182-6900(2460)$ & $6.0-371(126)$ & $2.3-148(55.4)$ & \begin{tabular}{|l|} 
Graham et \\
al., 2002 \\
\end{tabular} \\
\hline Rural & Dry & $\mathrm{PM}_{2.5}$ & $40-2660(1180)$ & $1.7-127(49.5)$ & $1.6-44.6(22.7)$ & \begin{tabular}{|l|} 
Graham et \\
al., 2002 \\
\end{tabular} \\
\hline Rural & Dry & $\mathrm{PM}_{2.5}$ & $446-4106(2006)$ & 21 - $259(116)$ & $7.6-61.5(31)$ & \begin{tabular}{|l|} 
Zdrahal et \\
al., 2002
\end{tabular} \\
\hline Rural & Dry & $\mathrm{PM}_{2.5}$ & $\begin{array}{l}1182-6900 \\
(2460)\end{array}$ & $6-371(126)$ & $2-148(55)$ & $\begin{array}{l}\text { Simoneit et } \\
\text { al., } 2004\end{array}$ \\
\hline Rural & Dry & $\mathrm{PM}_{2.5}$ & $284-7485(2222)$ & $23.7-543(152)$ & 7.7 - $261(58.7)$ & \begin{tabular}{|l|} 
Decesari et \\
al., 2006 \\
\end{tabular} \\
\hline Rural & Dry & $\mathrm{PM}_{2.5}$ & 763 - 7903 (3698) & $34.0-345(151)$ & $16.4-193(80.3)$ & $\begin{array}{l}\text { Decessari } \\
\text { et al., 2006 }\end{array}$ \\
\hline Suburban & Winter & $\mathrm{PM}_{10}$ & 134 - $971(407)$ & $34-286(116)$ & $1-7(2)$ & $\begin{array}{l}\text { Yttri et al., } \\
2007\end{array}$ \\
\hline Suburban & Winter & $\mathrm{PM}_{10}$ & $232-971(605)$ & 56 - $286(167)$ & $1.1-6.8(4.0)$ & $\begin{array}{l}\text { Yttri et al., } \\
2007\end{array}$ \\
\hline Suburban & ammer & $\mathrm{PM}_{10}$ & n.d. - 151 (47) & n.d. - $42(10)$ & n.d. - 7.5 (3) & \begin{tabular}{|l} 
Yttri et al., \\
2007
\end{tabular} \\
\hline
\end{tabular}




\begin{tabular}{|c|c|c|c|c|c|c|}
\hline Location & Season & $\left|\begin{array}{c}\text { Particle } \\
\text { Size }\end{array}\right|$ & $\begin{array}{c}\text { Levoglucosan } \\
\left.\text { (ng m }^{-3}\right) \\
\text { (Range } \\
\text { (ave)/Ave } \pm \text { S.D.) }\end{array}$ & 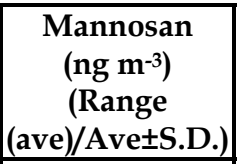 & 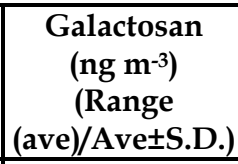 & Reference \\
\hline Urban & Winter & $\mathrm{PM}_{10}$ & 121 - $1133(477)$ & $17.3-153(66)$ & $4.4-44.2(19.6)$ & $\begin{array}{l}\text { Zdrahal et } \\
\text { al., } 2002\end{array}$ \\
\hline Urban & Winter & $\mathrm{PM}_{10}$ & 420 & 61 & 25 & $\begin{array}{l}\text { Pashynska } \\
\text { et al., 2002 }\end{array}$ \\
\hline Urban & Summer & $\mathrm{PM}_{10}$ & 19.1 & 3 & 1 & $\begin{array}{l}\text { Pashynska } \\
\text { et al., } 2002 \\
\end{array}$ \\
\hline Urban & Winter & $\mathrm{PM}_{10}$ & 121 - 1133 (477) & 17 - $153(66)$ & $4-44(20)$ & $\begin{array}{l}\text { Simoneit et } \\
\text { al., } 2004\end{array}$ \\
\hline Urban & Winter & TSP & $6-56$ & $0.2-15$ & $0.6-2.4$ & $\begin{array}{l}\text { Simoneit et } \\
\text { al., } 2004\end{array}$ \\
\hline Urban & Winter & TSP & $\begin{array}{l}1162-33400 \\
(14460)\end{array}$ & $\begin{array}{l}154-4430 \\
(1422)\end{array}$ & 84 - 2410 (1014) & $\begin{array}{l}\text { Simoneit et } \\
\text { al., } 2004\end{array}$ \\
\hline Urban & Winter & TSP & 1350 & 108 & 106 & $\begin{array}{l}\text { Simoneit et } \\
\text { al., } 2004\end{array}$ \\
\hline Urban & Winter & $\mathrm{PM}_{10}$ & n.d. - 475 (166) & n.d. - 155 (41) & n.d. - 17 (3) & $\begin{array}{l}\text { Yttri et al., } \\
2007\end{array}$ \\
\hline Urban & Summer & $\mathrm{PM}_{2.5}$ & $860-6090$ & $330-1090$ & $130-490$ & $\begin{array}{l}\text { Ward et } \\
\text { al., } 2006\end{array}$ \\
\hline Urban & Fall & $\mathrm{PM}_{10}$ & n.d. - 475 (193) & n.d. - 155 (52) & n.d. - 6.9 (1.7) & $\begin{array}{l}\text { Yttri et al., } \\
2007\end{array}$ \\
\hline Urban & Yearly & $\mathrm{PM}_{10}$ & $120-160(140)$ & $18-44(31)$ & $5-12(8.5)$ & $\begin{array}{l}\text { Caseiro et } \\
\text { al., } 2009\end{array}$ \\
\hline Urban & Yearly & $\mathrm{PM}_{10}$ & $250-480(380)$ & $37-114(84)$ & $14-37(28)$ & $\begin{array}{l}\text { Caseiro et } \\
\text { al., } 2009\end{array}$ \\
\hline Urban & Yearly & $\mathrm{PM}_{10}$ & 150 - $220(193)$ & $27-40(35)$ & $7-12(10)$ & $\begin{array}{l}\text { Caseiro et } \\
\text { al., } 2009\end{array}$ \\
\hline Urban & Winter & $\mathrm{PM}_{10}$ & $430-1894(901)$ & $22-134(54)$ & $30-186(96)$ & $\begin{array}{l}\text { Xie et al., } \\
2011\end{array}$ \\
\hline Urban & Spring & $\mathrm{PM}_{10}$ & $87-644(261)$ & $3.8-37(15)$ & $7.2-85(30)$ & $\begin{array}{l}\text { Xie et al., } \\
2010\end{array}$ \\
\hline Urban & Winter & $\mathrm{PM}_{1}$ & $422 \pm 165$ & $71.2 \pm 25.8$ & $19.5 \pm 7.67$ & $\begin{array}{l}\text { Krumal et } \\
\text { al., } 2010\end{array}$ \\
\hline Urban & Winter & $\mathrm{PM}_{2.5}$ & $572 \pm 71.3$ & $105 \pm 14.1$ & $48.7 \pm 2.92$ & $\begin{array}{l}\text { Krumal et } \\
\text { al., } 2010\end{array}$ \\
\hline Urban & Summer & $\mathrm{PM}_{10}$ & $15.6-472.9$ & & & $\begin{array}{l}\text { Zhang et } \\
\text { al., } 2010\end{array}$ \\
\hline Urban & Spring & $\mathrm{PM}_{2.5}$ & $26.2-133.7(36.0)$ & & & $\begin{array}{l}\text { Sang et al., } \\
2011\end{array}$ \\
\hline Suburban & Spring & $\mathrm{PM}_{2.5}$ & $21.1-91.5(30.0)$ & & & $\begin{array}{l}\text { Sang et al., } \\
2011\end{array}$ \\
\hline
\end{tabular}

Table 2. Ambient concentrations of anhydrosugars reported in the literature 


\begin{tabular}{|c|c|c|c|c|c|c|c|}
\hline $\begin{array}{l}\text { Biomass } \\
\text { type }\end{array}$ & $\begin{array}{c}\text { Combustion } \\
\text { type }\end{array}$ & Location & $\begin{array}{c}\text { Particle } \\
\text { size }\end{array}$ & Lev/Man & Lev/Gal & $\mid \begin{array}{c}\text { Lev/ } \\
\text { (Gal+Man) }\end{array}$ & Reference \\
\hline $\begin{array}{l}\text { Cereal } \\
\text { straw }\end{array}$ & $\begin{array}{c}\text { Chamber } \\
\text { burn }\end{array}$ & China & $\mathrm{PM}_{2.5}$ & 55.7 & & 52.4 & $\begin{array}{c}\text { Zhang et al., } \\
2007 \\
\end{array}$ \\
\hline Rice straw & $\begin{array}{c}\text { Chamber } \\
\text { burn }\end{array}$ & Taiwan & $\mathrm{PM}_{2.5}$ & 40 & 14.0 & 10.3 & $\begin{array}{c}\text { Engling et al., } \\
2009\end{array}$ \\
\hline Rice straw & $\begin{array}{c}\text { Chamber } \\
\text { burn }\end{array}$ & Bangladesh & $\mathrm{PM}_{2.5}$ & 41.6 & 25.1 & 15.6 & $\begin{array}{c}\text { Sheesley et al., } \\
2003\end{array}$ \\
\hline Sugarcane & $\begin{array}{l}\text { Chamber } \\
\text { burn }\end{array}$ & Malaysia & TSP & 12.7 & 12.7 & 6.4 & Oros et al., 2006 \\
\hline Peat & $\begin{array}{c}\text { Chamber } \\
\text { burn }\end{array}$ & $\begin{array}{l}\text { Sumatra, } \\
\text { Indonesia }\end{array}$ & $\mathrm{PM}_{10}$ & 11.4 & 28.1 & 8.1 & $\begin{array}{c}\text { Iinuma et al., } \\
2007\end{array}$ \\
\hline Leaves & $\begin{array}{l}\text { Open air } \\
\text { burning }\end{array}$ & $\begin{array}{l}\text { Lower- } \\
\text { Austria }\end{array}$ & PM10 & 5.5 & 1.3 & 1.0 & \begin{tabular}{|c|} 
Schmidl et al., \\
2008
\end{tabular} \\
\hline Pine & $\begin{array}{c}\text { Chamber } \\
\text { burn }\end{array}$ & Germany & $\mathrm{PM}_{10}$ & 3.8 & 5.0 & 2.1 & $\begin{array}{c}\text { Iinuma et al., } \\
2007\end{array}$ \\
\hline Pine & Wildfire & Canada & & 2.5 & 10.0 & 2.0 & Otto et al., 2006 \\
\hline Pine & $\begin{array}{c}\text { Chamber } \\
\text { burn }\end{array}$ & US & $\mathrm{PM}_{2.5}$ & 3.0 & 12.6 & 2.4 & $\begin{array}{c}\text { Engling et al., } \\
2006 a\end{array}$ \\
\hline Spruce & $\begin{array}{c}\text { Residential } \\
\text { stove }\end{array}$ & Austria & $\mathrm{PM}_{10}$ & 3.6 & 12.6 & 2.8 & \begin{tabular}{|c|} 
Schmidl et al., \\
2008 \\
\end{tabular} \\
\hline $\begin{array}{l}\text { White } \\
\text { spruce }\end{array}$ & $\begin{array}{c}\text { Residential } \\
\text { fireplace }\end{array}$ & $\begin{array}{l}\text { Western } \\
\text { US }\end{array}$ & $\mathrm{PM}_{2.5}$ & 3.9 & 14.2 & 3.1 & Fine et al., 2004 \\
\hline Douglas fir & $\begin{array}{c}\text { Residential } \\
\text { fireplace }\end{array}$ & $\begin{array}{l}\text { Western } \\
\text { US }\end{array}$ & $\mathrm{PM}_{2.5}$ & 4.4 & 22.6 & 3.7 & Fine et al., 2004 \\
\hline Hemlock & $\begin{array}{c}\text { Residential } \\
\text { fireplace }\end{array}$ & \begin{tabular}{|c|} 
North- \\
Eastern US
\end{tabular} & $\mathrm{PM}_{2.5}$ & 3.7 & 38.7 & 3.4 & Fine et al., 2001 \\
\hline Cottonwood & $\begin{array}{l}\text { Chamber } \\
\text { burn }\end{array}$ & US & $\mathrm{PM}_{2.5}$ & 14 & 23.4 & 8.7 & $\begin{array}{c}\text { Engling et al., } \\
2006 a\end{array}$ \\
\hline Beech & $\begin{array}{c}\text { Residential } \\
\text { stove }\end{array}$ & Austria & $\mathrm{PM}_{10}$ & 14.6 & 20.5 & 8.5 & \begin{tabular}{|c|} 
Schmidl et al., \\
2008
\end{tabular} \\
\hline Musasa & $\begin{array}{l}\text { Chamber } \\
\text { burn }\end{array}$ & Africa & $\mathrm{PM}_{10}$ & 22.7 & 25.0 & 11.9 & $\begin{array}{c}\text { Iinuma et al., } \\
2007\end{array}$ \\
\hline White oak & $\begin{array}{c}\text { Residential } \\
\text { fireplace }\end{array}$ & $\begin{array}{l}\text { Western } \\
\text { US }\end{array}$ & $\mathrm{PM}_{2.5}$ & 12.9 & 20.4 & 7.9 & Fine et al., 2004 \\
\hline $\begin{array}{l}\text { Sugar } \\
\text { maple }\end{array}$ & $\begin{array}{c}\text { Residential } \\
\text { fireplace }\end{array}$ & $\begin{array}{l}\text { Western } \\
\text { US }\end{array}$ & $\mathrm{PM}_{2.5}$ & 19.8 & 84.0 & 16.0 & Fine et al.,2004 \\
\hline Red maple & $\begin{array}{c}\text { Residential } \\
\text { fireplace }\end{array}$ & \begin{tabular}{|c|} 
North- \\
Eastern US
\end{tabular} & $\mathrm{PM}_{2.5}$ & 33.2 & & 33.2 & Fine et al., 2001 \\
\hline Red oak & $\begin{array}{c}\text { Residential } \\
\text { fireplace }\end{array}$ & \begin{tabular}{|c|} 
North- \\
Eastern US
\end{tabular} & $\mathrm{PM}_{2.5}$ & 35.4 & 47.7 & 20.3 & Fine et al., 2001 \\
\hline
\end{tabular}

Table 3. The ratios of Lev/Man, Lev/Gal and Lev/(Gal+Man) for various types of biomass

The ratios of levoglucosan to other anhydrosugars in biomass burning smoke particles can be used to identify the specific biomass burning types. For example, levoglucosan to 
mannosan (Lev/Man) could be used to distinguish the biomass/biofuel types, such as softwood versus hardwood or coniferous versus deciduous wood (Ward et al., 2006; Oliveira et al., 2007; Pio et al., 2008; Schmidl et al., 2008a; 2008b; Engling et al., 2009). Galactosan is usually 10-50 times less abundant in smoke PM than levoglucosan and 1-3 times lower than mannosan levels (Schmidl et al., 2008a). The levoglucosan/galactosan (Lev/Gal) ratio, for example, has been used to distinguish smoke aerosol from leaf and wood burning (Schmidl et al., 2008a). Moreover, levoglucosan to mannosan (Lev/Man) and levoglucosan to mannosan plus galactosan (Lev/(Man+Gal)) ratios were proposed as discriminators of smoke aerosol from lignite and extant biomass due to the lower galactosan content in lignite (Fabbri et al., 2009).

Table 3 summarizes the typical Lev/Man ratios for various biomass/biofuels reported in the literature. Sheesley et al. (2003) reported a Lev/Man ratio in $\mathrm{PM}_{2.5}$ for rice straw burning in Bangladesh of 41.6, similar to the ratio of 40 found for rice straw in Taiwan (Engling et al., 2009), while that of mixed cereal straw (wheat, rice and corn) in China was 55.7 (Zhang et al., 2007). Compared with rice straw burning, the ratios of sugarcane and bamboo smoke in the same grass family are relatively low with a range of 5-13, while that of peanuts in the bean family was in the range of sugarcane and bamboo (Oros et al., 2006; Iinuma et al., 2007) (Table 3). The Lev/Man ratio for soft wood (spruce, fir and pine) ranged from 3-6 in the US (Fine et al., 2001; Fine et al., 2004b) and 2.5-4 in Germany, Austria and Canada (Otto et al., 2006; Iinuma et al., 2007; Schmidl et al., 2008b) (Table 3). Fine et al. (2001; 2004b) and Engling et al. (2006a) showed that the Lev/Man ratios for hard wood (oak, maple, beech, cherry and aspen) varied from 13-35, while it was 12.5-22.7 for beech and musasa (Iinuma et al., 2007; Schmidl et al., 2008b) in Austria and Africa (Table 3). Thus, we could conclude that the Lev/Man ratios could be used to at least differentiate soft wood (2-6), hard wood (13-35), and crop residue (40-55.7).

\section{Size-resolved composition of biomass burning smoke}

The investigation of the size-resolved composition of biofuel burning smoke has recently gained attention in source/near source and ambient studies. Typically, biofuel smoke emissions are characterized by predominantly fine $(<2.5 \mu \mathrm{m}$ aerodynamic diameter $)$ particles (Engling et al., 2006b), which has also been observed in ambient aerosol particles influenced by biomass/biofuel smoke (Wang et al., 2009). For instance, carbonaceous aerosol and biomass smoke markers in particular were found predominantly in submicron particles during a long-range transport episode of wood smoke effecting Yosemite National Park in California, US (Herckes et al., 2006). A temporal variation in PM size distributions suggested a certain dependence on the burning process or atmospheric processing of the smoke particles. In contrast, a substantial mass fraction of the anhydrosugar tracers, including levoglucosan, was recently found in aerosol particles with diameters larger than $10 \mu \mathrm{m}$ in ambient aerosols (Lee et al., 2008), indicating possible influence by the ambient atmospheric conditions, such as high relative humidity, in addition to unique properties of the biofuel and the specific burning practices.

Likewise, a distinct bimodal distribution was observed with a large fraction of levoglucosan present in a super-coarse mode $(>10 \mu \mathrm{m}$ aerodynamic particle diameter) as well as a fine mode $(<0.49 \mu \mathrm{m}$ aerodynamic particle diameter) in a rice straw field burning study conducted by Engling et al. (2009) (Figure 5). In a more precise size distribution study, Wang et al. (2009) reported that concentrations of particulate matter (PM) mass, n-alkanes, 
and low molecular weight (LMW) PAHs and levoglucosan showed a unimodal size distribution, peaking at 0.7-1.1 $\mu \mathrm{m}$ during the hazy days impacted by wheat straw burning, and a bimodal distribution, peaking at 0.7-1.1 $\mu \mathrm{m}$ and $4.7-5.8 \mu \mathrm{m}$ in normal days.

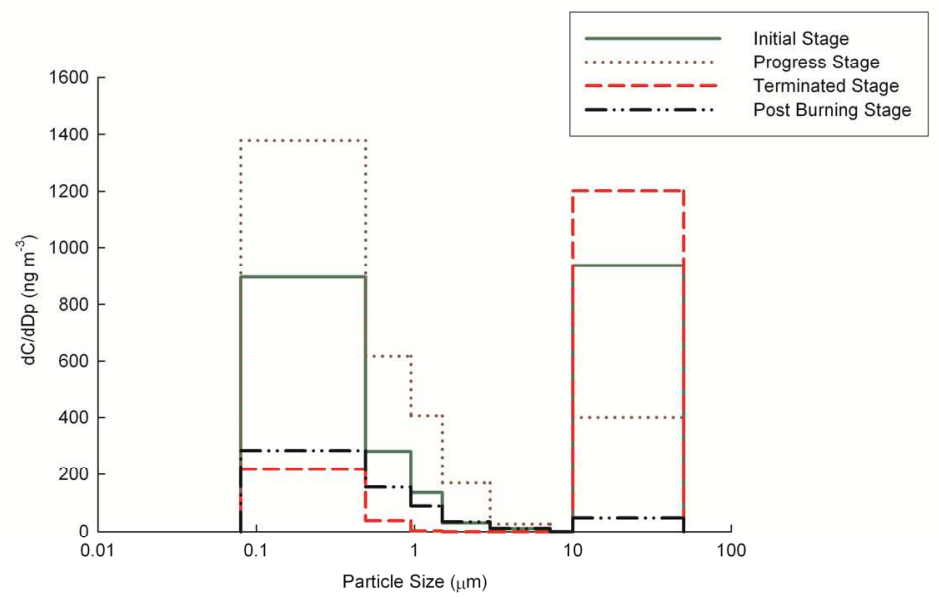

Fig. 5. Levoglucosan size distributions based on 7 particle size ranges $(<0.49 \mu \mathrm{m} ; 0.49-0.95$ $\mu \mathrm{m} ; 0.95-1.5 \mu \mathrm{m} ; 1.5-3 \mu \mathrm{m} ; 3-7.2 \mu \mathrm{m} ; 7.2-10 \mu \mathrm{m}$; and 10-50 $\mu \mathrm{m}$ ) in smoke particles generated during field burning of rice straw

\section{Chemical analysis methods}

Much effort has been put into developing methods for the quantification of biomass burning products and particularly the smoke tracers, such as the anhydrosugars. Both gas chromatographic (GC) and aqueous-phase methods have been reported (Schkolnik and Rudich, 2006). The former methods are the most common ones with good separation and high sensitivity by utilizing mass spectrometric (MS) detectors (Zdrahal et al., 2002), but require complex sample preparation, large amounts of solvents, and expensive equipment. The latter ones, including Electrospray Ionization-Mass Spectrometry (ESI-MS) (Wan and $\mathrm{Yu}, 2006)$, Microchip Capillary Electrophoresis (microchip-CE) with Pulsed Amperometric Detection (PAD) (Garcia et al., 2005), Ion-exclusion Chromatography (IEC) (Schkolnik et al., 2005), High Performance Liquid Chromatography (HPLC) (Dye and Yttri, 2005; Dixon and Baltzell, 2006), and High Performance Anion Exchange Chromatography (HPAEC) coupled with PAD or MS (Engling et al., 2006a), have been developed more recently and are, therefore, at present applied less frequently for the quantification of levoglucosan and other biomass/biofuel combustion products. However, these methods are rapidly gaining attention due to their speed and no need for chemical derivatizations (Ma et al., 2010). The IEC-HPLC-PDA method, for instance, is suitable for measuring levoglucosan, inorganic ions and carboxylic acids in a large set of water-extracted aerosols or aqueous samples. HPLCESI-MS has been shown to completely separate levoglucosan from its isomers in concentrations ranging from background to polluted levels with short sample preparation, good separation and high sensitivity. However, for detailed organic speciation of smaller sets of samples, GC-MS analysis remains the method of choice to date. 
Recently, stable carbon isotope analysis is emerging as a powerful tool to provide additional constraints on the atmospheric budgets, and to increase our understanding of source emissions and ambient aerosols influenced by biomass burning (Goldstein and Shaw, 2003; Huang et al., 2006) and secondary formation processes (Fisseha et al., 2009a). Stable carbon isotopic composition can be determined for both bulk material (e.g., total carbon) and for individual compounds (Hoefs, 1987; Flanagan et al., 2005). However, until recently few studies have applied stable isotope measurements to atmospheric chemistry and particularly for biomass burning aerosols (Rudolph, 2007). The measurement of isotopic ratios for the biomass burning tracer levoglucosan is still not explored because of the high polarity of the sugars and the resulting difficult separation. Martinelli et al. (2002) determined the bulk stable carbon isotopic composition of organic matter in aerosols in order to assess sugar cane sources. Rudolph et al. (1997) and Iannone et al. (2007) presented a new method named gas chromatography coupled to isotope ratio mass spectrometry (GCC-IRMS) to determine the isotopic ratio of volatile organic carbons (VOCs). Fisseha et al. (2009a) determined the $\delta^{13} \mathrm{C}$ values of formic, acetic and oxalic acid in ambient gas and aerosol phases using a wet oxidation method followed by isotope ratio mass spectrometry. The first chamber study of investigating the stable carbon isotopic composition of secondary organic aerosol (SOA) formed from ozonolysis of $\beta$-pinene was conducted by Fisseha et al. (2009b). As for biomass burning aerosols, O'Malley et al. (1997) and Czapiewski et al. (2002) determined the isotopic composition of the non-methane hydrocarbons in emissions from biomass burning by using a GC-MS/C/IRMS system.

\section{Impact of biomass burning smoke}

The influence of smoke emissions from biomass/biofuel burning on the immediate surroundings and on areas downwind of the fire activity can be manifold. In this section, findings from several case studies are used to demonstrate the significant impacts that can be exerted by biomass smoke particles. The importance of the impact of biomass burning in the tropics on atmospheric chemistry and biogeochemical cycles was pointed out in the early 1990s by Curtzen and Andreae (1990). South and Southeast Asia are the two major biomass burning source regions in the world with natural forest fires and human initiated burning activities (Haberle et al., 2001; Pochanart et al., 2003; Radojevic, 2003; Sheesley et al., 2003; Venkataraman et al., 2005; Hasan et al., 2009; Chang and Song, 2010; Ram and Sarin, 2010). Chan et al. (2000) first showed with in-situ sounding measurements, satellite data and trajectory analyses that the frequently observed springtime ozone enhancements in the lower troposphere over Hong Kong were due to photochemical reactions during the transport of ozone precursors originating from the upwind Southeast Asian subcontinent, where intensive biomass burning activities occur during each spring. The enhanced ozone accompanied with a layer of increased biomass burning tracers, such as methyl chloride and carbonaceous aerosol, was shown to further extend to other parts of subtropical south China, the east Asian coast and western Pacific (Chan et al., 2003a,b).

In addition, aircraft and mountain-top measurements have shown that smoke aerosol derived from biomass burning activities in Southeast and East Asia can be transported eastward towards (and across) the Pacific Ocean (Bey et al., 2001; Jacob et al., 2003; Ma et al., 2003b). Ma et al. (2003a) observed biomass burning plumes with enhanced fine particle potassium and $\mathrm{CO}$ concentrations originating from Southeast Asia during the experimental period of the Transport and Chemical Evolution over the Pacific (TRACE-P) campaign in 
March, 2001. Lin et al. (2010) observed elevated carbon monoxide (CO) mixing ratios in central Taiwan due to biomass burning activities in the Asian continent, including India, the Indochina Peninsula and south Coastal China from January to April 2008. Stohl et al. (2007) predicted that an air pollution plume in the upper troposphere over Europe on 24-25 March 2006 originated from Southern and Eastern Asia with the FLEXPART particle dispersion model. Most recently, it was shown that biomass (rice straw) smoke generated in the Philippines could be transported to southeast coastal China and can contribute to $16-28 \%$ of the ambient OC burden in the background atmosphere during spring (Zhang et al., 2011).
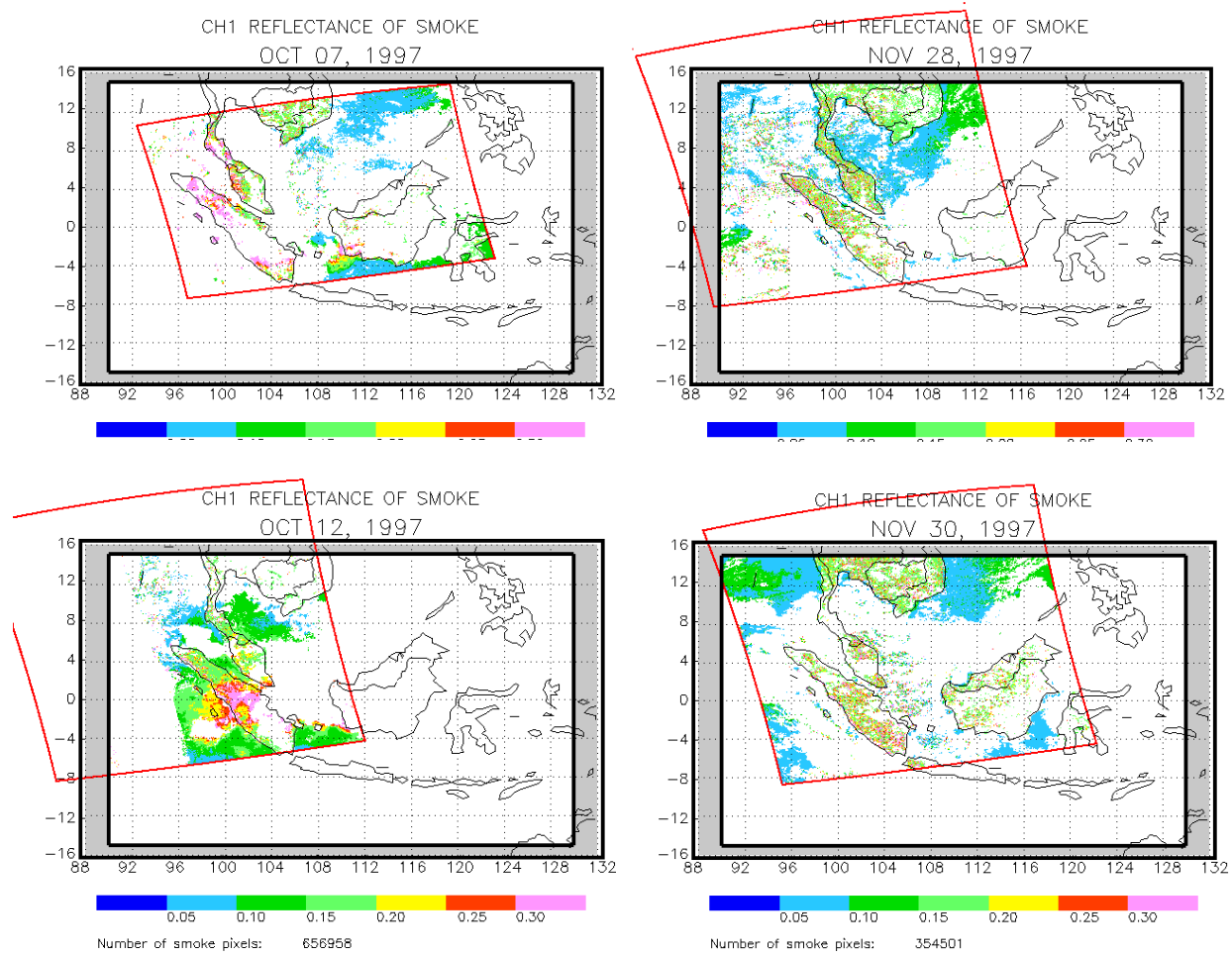

Fig. 6. Smoke pixels estimated from AVHRR on (left) October 7 and 12, and (right)

November 28 and 30, 1997 during the Indonesian forest fire period in 1997. The borders indicate the coverage area of the satellite images

During the extreme El Nino period in 1997, when agricultural burning went out of control and resulted in widespread forest fires in Indonesia, Chan et al. (2003b) showed that the smoke aerosol can span over large gographical regions to high latitudes of south China (Figure 6), while Thompson et al. (2001) reported that it can reach longitudially as far as to the Indian Ocean. Chan et al. (2003b) further showed with evidence form in-situ ozonesonde measurements and empirical formulation results that such large-scale biomass burning can result in significant changes in atmospheric composition and radiative forcing in tropical 
and subtropical Asia and the western Pacific. Furthermore, Wang et al. (2007b) reported that plumes of biomass burning aerosols in South Asia had been extended to the Indian Ocean and the western Pacific Ocean.

The Tibetan Plateau is the largest plateau in the world, which exerts profound effects on the regional and global radiative budget and climate (Lau et al., 2006; Wang et al., 2006). However, scarce data of trace gases and aerosols were observed in this region, let alone biomass burning smoke aerosol. Chan et al. (2006) showed that pollution from active fire regions of Southeast Asia and South Asia had relatively strong impact on the abundance of $\mathrm{O}_{3}$, trace gases and aerosols in the background atmosphere of the Tibetan Plateau. According to the characteristic levoglucosan/mannosan (Lev/Man) ratios, Sang et al. (2011) identified for the first time that a mountain site in the Tibetan Plateau was affected by longrange transported biomass burning smoke derived from soft wood and crop residue burning in South/Southeast Asia, while a suburban site was mainly affected by local (residential) soft-wood burning. At a remote mountain site in the southeastern part of the Tibetan Plateau during spring, Engling et al. (2011) showed a substantial regional build-up of BC and other aerosol components during the dry period, accompanied by fire activities and transport of pollution from the nearby regions of Southeast Asia and the northern part of the Indian Peninsula (Figure 7). Moreover, BC and aerosol mass concentrations during episodic events were found to be comparable to those reported for certain large Asian cities, mainly due to influence from biomass/biofuel smoke.

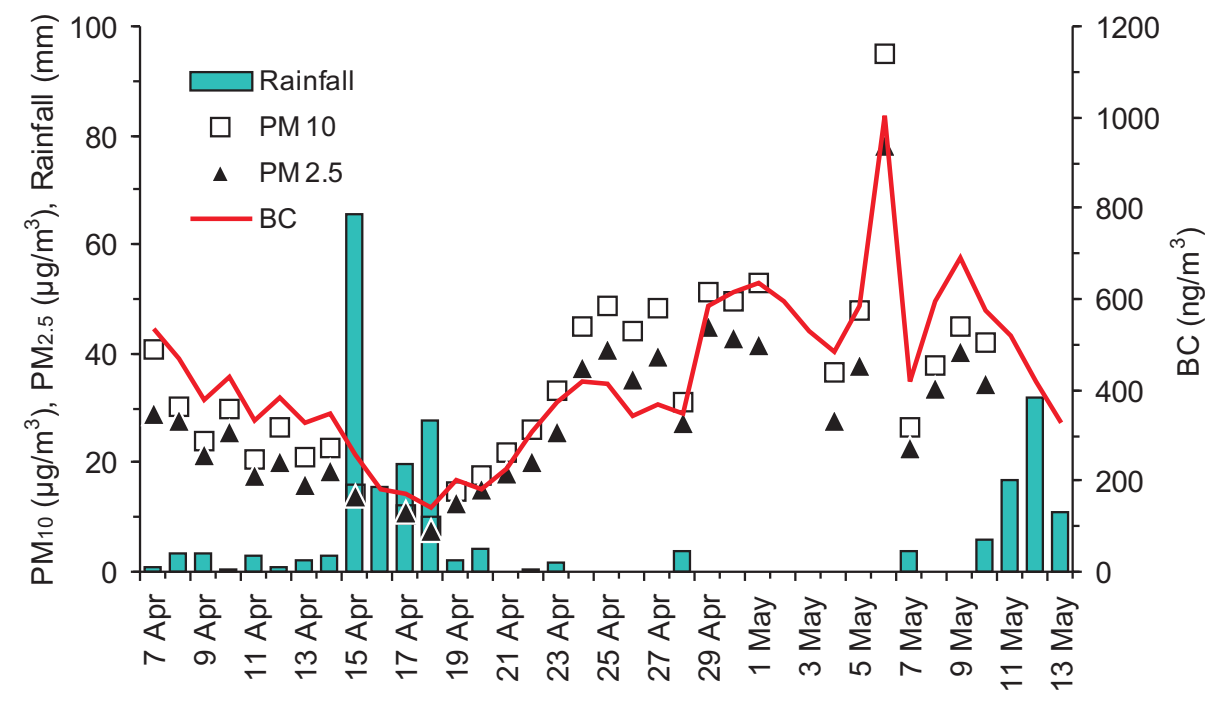

Fig. 7. Daily average concentrations of $\mathrm{PM}_{2.5}, \mathrm{PM}_{10}$, black carbon and rainfall at a remote mountain site in the southeastern Tibetan Plateau at Tengchong during April-May 2004

In the highly developed Pearl River Delta, biomass smoke contributes a sizeable portion of the ambient aerosol mass as well, as shown by high concentrations of the biomass burning gas-phase tracer $\mathrm{CH}_{3} \mathrm{Cl}$ (Chan et al., 2003a). The biomass burning smoke contributions to 
fine particles were 3-19\% (Wang et al., 2007a) and to organic carbon in $\mathrm{PM}_{10}$ were $7.0-14 \%$ (Zhang et al., 2010) in Guangzhou. Aerosols in Beijing were heavily influenced by different kinds of biofuel burning all year long. The wheat harvest season in summer is the most intensive period, while biomass smoke influence could be detected in spring (due to field preparation burning) and autumn as well (burning of maize residue and fallen dead leaves) (Duan et al., 2004). The contributions from biofuel burning were $18-38 \%$ and $14-32 \%$ to the $\mathrm{PM}_{2.5}$ and $\mathrm{PM}_{10}$ organic carbon in Beijing, respectively (Zhang et al., 2008).

\section{Conclusions}

The combustion of biomass/biofuels for agricultural residue removal and domestic use (for cooking and heating) is a major source of smoke emissions, in addition to large-scale savanna and forest fires, on a global scale. The Asian continent in particular is a major source region of smoke aerosol. As most of these burning processes occur with little/no control and at low combustion efficiency, the amount of smoke emitted and the resulting effects on air quality and global climate are substantial. While importnat advances have been made lately, by conducting detailed source emissions studies and using novel chemical analysis methods for smoke particle characterization, the uncertainty in the estimates of biofuel smoke emissions and their environmental effects remains rather large. It is, therefore, critical to assess the particle-size dependent chemical composition and physical as well as optical properties of biomass/biofuel smoke particles in future source and ambient studies.

\section{Acknowledgement}

This study was supported through a key project of the Natural Science Foundation of Guangdong Province, China (No. 825102501000002) and the National Natural Science Foundation of China (No. 40875075) and a joint fund of the National Natural Science Foundation of China and Natural Science Foundation of Guangdong Province, China (No. U0833001).

\section{References}

Akagi, S. K., R. J. Yokelson, C. Wiedinmyer, M. J. Alvarado, J. S. Reid, T. Karl, J. D. Crounse and Wennberg, P. O. (2010). Emission factors for open and domestic biomass burning for use in atomospheric models. Atmospheric Chemistry and Physics Discussions 10, pp. 27523-27602, doi: 10.5194/acpd-10-27523-2010.

Andreae, M. O. and Merlet, P. (2001). Emission of trace gases and aerosols from biomass burning. Global Biogeochemical Cycles 15, pp. 955-966.

Bey, I., Jacob, D. J., Logan, J. A. and Yantosca, R. M. (2001). Asian chemical outflow to the Pacific in spring: Origins, pathways, and budgets. J. Geophys. Res. 106, pp. 2309723113, doi: 10.1029/2001jd000806.

Caseiro, A., Bauer, H., Schmidl, C., Pio, C. A. and Puxbaum, H. (2009). Wood burning impact on PM10 in three Austrian regions. Atmospheric Environment 43, pp. 2186$2195 i$. 
Chan, C. Y. and Chan, L. Y. (2000). Effect of meteorology and air pollutant transport on ozone episodes at a subtropical coastal Asian city, Hong Kong. Journal of Geophysical Research 105, pp. 20707-20724, doi: 10.1029/2000jd900140.

Chan, C. Y., Chan, L. Y., Chang, W. L., Zheng, Y. G., Cui, H., Zheng, X. D., Qin, Y. and Li, Y. S. (2003a). Characteristics of a tropospheric ozone profile and implications for the origin of ozone over subtropical China in the spring of 2001. Journal of Geophysical Research 108, Doi: 10.1029/2003jd003427.

Chan, C. Y., Chan, L. Y., Harris, J. M., Oltmans, S. J., Blake, D. R., Qin, Y., Zheng, Y. G. and Zheng, X. D. (2003b). Characteristics of biomass burning emission sources, transport, and chemical speciation in enhanced springtime tropospheric ozone profile over Hong Kong. Journal of Geophysical Research 108, Doi: 10.1029/2001JD001555.

Chan, C. Y., Wong, K. H., Li, Y. S., Chan, L. Y. and Zheng, X. D. (2006). The effects of Southeast Asia fire activities on tropospheric ozone, trace gases and aerosols at a remote site over the Tibetan Plateau of Southwest China. Tellus B 58, pp. 310-318, doi: DOI 10.1111/j.1600-0889.2006.00187.x.

Chang, D. and Song, Y. (2010). Estimates of biomass burning emissions in tropical Asia based on satellite-derived data. Atmospheric Chemistry and Physics 10, pp. 2335-2351.

Christian, T. J., Kleiss, B., Yokelson, R. J., Holzinger, R., Crutzen, P. J., Hao, W. M., Saharjo, B. H. and Ward, D. E. (2003). Comprehensive laboratory measurements of biomassburning emissions: 1. Emissions from Indonesian, African, and other fuels. Journal of Geophysical Research 108.

Christopher, D. and Kimberly, E. (1996). Survey of fires in Southeast Asia and India during 1987. Global Biomass Burning 2, pp. 663-670.

Crutzen, P. J. and Andreae, M. O. (1990). Biomass Burning in the Tropics - Impact on Atmospheric Chemistry and Biogeochemical Cycles. Science 250, pp. 1669-1678.

Czapiewski, K. V., Czuba, E., Huang, L., Ernst, D., Norman, A. L., Koppmann, R. and Rudolph, J. (2002). Isotopic composition of non-methane hydrocarbons in emissions from biomass burning. Journal of Atmospheric Chemistry 43, pp. 45-60.

Decesari, S., Fuzzi, S., Facchini, M. C., Mircea, M., Emblico, L., Cavalli, F., Maenhaut, W., Chi, X., Schkolnik, G., Falkovich, A., Rudich, Y., Claeys, M., Pashynska, V., Vas, G., Kourtchev, I., Vermeylen, R., Hoffer, A., Andreae, M. O., Tagliavini, E., Moretti, F. and Artaxo, P. (2006). Characterization of the organic composition of aerosols from Rondonia, Brazil, during the LBA-SMOCC 2002 experiment and its representation through model compounds. Atmospheric Chemistry and Physics 6, pp. 375-402.

Dixon, R. W. and Baltzell, G. (2006). Determination of levoglucosan in atmospheric aerosols using high performance liquid chromatography with aerosol charge detection. Journal of Chromatography A 1109, pp. 214-221, doi.

Duan, F., Liu, X., Yu, T. and Cachier, H. (2004). Identification and estimate of biomass burning contribution to the urban aerosol organic carbon concentrations in Beijing. Atmospheric Environment 38, pp. 1275-1282, doi.

Dwyer, E., Grégoire, J. M. and Malingreau, J. P. (1998). A global analysis of vegetation fires using satellite images: Spatial and temporal dynamics. Ambio 27, pp. 175-181.

Dye, C. and Yttri, K. E. (2005). Determination of Monosaccharide Anhydrides in Atmospheric Aerosols by Use of High-Performance Liquid Chromatography 
Combined with High-Resolution Mass Spectrometry. Analytical Chemistry 77, pp. 1853-1858, doi: 10.1021/ac049461j.

Engling, G., Carrico, C. M., Kreldenweis, S. M., Collett, J. L., Day, D. E., Malm, W. C., Lincoln, E., Hao, W. M., Iinuma, Y. and Herrmann, H. (2006a). Determination of levoglucosan in biomass combustion aerosol by high-performance anion-exchange chromatography with pulsed amperometric detection. Atmospheric Environment 40, pp. S299-S311, doi: Doi: 10.1016/j.atmosenv.2005.12.069.

Engling, G., Herckes, P., Kreidenweis, S. M., Malm, W. C. and Collett, J. J. L. (2006b). Composition of the fine organic aerosol in Yosemite National Park during the 2002 Yosemite Aerosol Characterization Study. Atmospheric Environment 40, pp. 29592972.

Engling, G., Lee, J. J., Tsai, Y.-W., Lung, S. C. C., Chou, C. C. K. and Chan, C. Y. (2009). SizeResolved Anhydrosugar Composition in Smoke Aerosol from Controlled Field Burning of Rice Straw. Aerosol Science and Technology 43, pp. 662-672.

Engling, G., Zhang, Y.-N., Chan, C.-Y., Sang, X.-F., Lin, M., Ho, K.-F., Li, Y.-S., Lin, C.-Y. and Lee, J. J. (2011). Characterization and sources of aerosol particles over the southeastern Tibetan Plateau during the Southeast Asia biomass-burning season. Tellus B 63, pp. 117-128, doi: 10.1111/j.1600-0889.2010.00512.x.

Fabbri, D., Torri, C., Simonei, B. R. T., Marynowski, L., Rushdi, A. I. and Fabianska, M. J. (2009). Levoglucosan and other cellulose and lignin markers in emissions from burning of Miocene lignites. Atmospheric Environment 43, pp. 2286-2295, doi: DOI 10.1016/j.atmosenv.2009.01.030.

Fine, P. M., Cass, G. R. and Simoneit, B. R. T. (2001). Chemical characterization of fine particle emissions from fireplace combustion of woods grown in the northeastern United States. Environmental Science E Technology 35, pp. 2665-2675.

Fine, P. M., Cass, G. R. and Simoneit, B. R. T. (2002). Chemical Characterization of Fine Particle Emissions from the Fireplace Combustion of Woods Grown in the Southern United States. Environmental Science \& Technology 36, pp. 1442-1451, doi: 10.1021/es0108988.

Fine, P. M., Cass, G. R. and Simoneit, B. R. T. (2004a). Chemical characterization of fine particle emissions from the wood stove combustion of prevalent United States tree species. Environmental Engineering Science 21, pp. 705-721.

Fine, P. M., Cass, G. R. and Simoneit, B. R. T. (2004b). Chemical characterization of fine particle emissions from the fireplace combustion of wood types grown in the Midwestern and Western United States. Environmental Engineering Science 21, pp. 387-409.

Fisseha, R., Saurer, M., Jaggi, M., Siegwolf, R. T. W., Dommen, J., Szidat, S., Samburova, V. and Baltensperger, U. (2009a). Determination of primary and secondary sources of organic acids and carbonaceous aerosols using stable carbon isotopes. Atmospheric Environment 43, pp. 431-437, doi: 10.1016/j.atmosenv.2008.08.041.

Fisseha, R., Spahn, H., Wegener, R., Hohaus, T., Brasse, G., Wissel, H., Tillmann, R., Wahner, A., Koppmann, R. and Kiendler-Scharr, A. (2009b). Stable Carbon Isotope Composition of Secondary Organic Aerosol from b-Pinene Oxidation. Journal of Geophysical Research 114, Doi: 10.1029/2008jd011326.

Flanagan, L. B., Ehleringer, J. R. and Pataki, D. E., (2005). Stable isotopes and biosphereatmosphere interactions. Elsevier Academic Press, 0-12-088447-x, California. 
Fraser, M. P. and Lakshmanan, K. (2000). Using levoglucosan as a molecular marker for the long-range transport of biomass combustion aerosols. Environmental Science $\mathcal{E}$ Technology 34, pp. 4560-4564, doi: Doi 10.1021/Es9912291.

Garcia, C. D., Engling, G., Herckes, P., Collett, J. L., Jr. and Henry, C. S. (2005). Determination of Levoglucosan from Smoke Samples Using Microchip Capillary Electrophoresis with Pulsed Amperometric Detection. Environmental Science \& Technology 39, pp. 618-623.

Goldstein, A. H. and Shaw, S. L. (2003). Isotopes of Volatile Organic Compounds: An Emerging Approach for Studying Atmospheric Budgets and Chemistry. Chemical Reviews 103, pp. 5025-5048, doi: 10.1021/cr0206566.

Graham, B., Mayol-Bracero, O. L., Guyon, P., Roberts, G. C., Decesari, S., Facchini, M. C., Artaxo, P., Maenhaut, W., Koll, P. and Andreae, M. O. (2002). Water-soluble organic compounds in biomass burning aerosols over Amazonia - 1. Characterization by NMR and GC-MS. Journal of Geophysical Research-Atmospheres 107, Doi 10.1029/2001jd000336.

Haberle, S. G., Hope, G. S. and van der Kaars, S. (2001). Biomass burning in Indonesia and Papua New Guinea: natural and human induced fire events in the fossil record. Palaeogeography Palaeoclimatology Palaeoecology 171, pp. 259-268.

Hasan, M., Salam, A. and Alam, A. M. S. (2009). Identification and characterization of trace metals in black solid materials deposited from biomass burning at the cooking stoves in Bangladesh. Biomass and Bioenergy 33, pp. 1376-1380.

Hays, M. D., Geron, C. D., Linna, K. J., Smith, N. D. and Schauer, J. J. (2002). Speciation of gas-phase and fine particle emissions from burning of foliar fuels. Environmental Science \& Technology 36, pp. 2281-2295, doi.

Hennigan, C. J., Sullivan, A. P., Collett, J. L. and Robinson, A. L. (2010). Levoglucosan stability in biomass burning particles exposed to hydroxyl radicals. Geophysical Research Letters 37, Doi: 10.1029/2010gl043088.

Herckes, P., Engling, G., Kreidenweis, S. M. and Collett, J. L. (2006). Particle size distributions of organic aerosol constituents during the 2002 Yosemite Aerosol Characterization Study. Environmental Science \& Technology 40, pp. 4554-4562, Doi: 10.1021/Es0515396.

Hoefs, J., (3rd ed). (1987). Stable Isotope Geochemistry. Springer-Verlag, Berlin.

Hoffmann, D., Tilgner, A., Iinuma, Y. and Herrmann, H. (2010). Atmospheric Stability of Levoglucosan: A Detailed Laboratory and Modeling Study. Environmental Science \& Technology 44, pp. 694-699, doi: Doi 10.1021/Es902476f.

Huang, L., Brook, J. R., Zhang, W., Li, S. M., Graham, L., Ernst, D., Chivulescu, A. and Lu, G. (2006). Stable isotope measurements of carbon fractions (OC/EC) in airborne particulate: A new dimension for source characterization and apportionment. Atmospheric Environment 40, pp. 2690-2705.

Iannone, R., Koppmann, R. and Rudolph, J. (2007). A technique for atmospheric measurements of stable carbon isotope ratios of isoprene, methacrolein, and methyl vinyl ketone. Journal of Atmospheric Chemistry 58, pp. 181-202, doi: 10.1007/s10874007-9087-5.

Iinuma, Y., Bruggemann, E., Gnauk, T., Muller, K., Andreae, M. O., Helas, G., Parmar, R. and Herrmann, H. (2007). Source characterization of biomass burning particles: The combustion of selected European conifers, African hardwood, savanna grass, and 
German and Indonesian peat. Journal of Geophysical Research-Atmospheres 112, Doi: 10.1029/2006jd007120.

Jacob, D. J., Crawford, J. H., Kleb, M. M., Connors, V. S., Bendura, R. J., Raper, J. L., Sachse, G. W., Gille, J. C., Emmons, L. and Heald, C. L. (2003). Transport and Chemical Evolution over the Pacific (TRACE-P) aircraft mission: Design, execution, and first results. J. Geophys. Res. 108, Doi: 10.1029/2002jd003276.

Krumal, K., Mikuska, P., Vojtesek, M. and Vecera, Z. (2010). Seasonal variations of monosaccharide anhydrides in PM1 and PM2.5 aerosol in urban areas. Atmospheric Environment 44, pp. 5148-5155.

Lau, K. M., Kim, M. K. and Kim, K. M. (2006). Asian summer monsoon anomalies induced by aerosol direct forcing: the role of the Tibetan Plateau. Climate Dynamics 26, pp. 855-864, doi: 10.1007/s00382-006-0114-z.

Lawson, D. R. and Winchester, J. W. (1979). Sulfur, Potassium, and Phosphorus Associations in Aerosols from South-American Tropical Rain Forests. Journal of Geophysical Research - Oceans and Atmospheres 84, pp. 3723-3727.

Lee, J. J., Engling, G., Candice Lung, S.-C. and Lee, K.-Y. (2008). Particle size characteristics of levoglucosan in ambient aerosols from rice straw burning. Atmospheric Environment 42, pp. 8300-8308.

Lin, Y. C., Lin, C. Y. and Hsu, W. T. (2010). Observations of carbon monoxide mixing ratios at a mountain site in central Taiwan during the Asian biomass burning season. Atmospheric Research 95, pp. 270-278, doi: 10.1016/j.atmosres.2009.10.006.

Liu, H., Chang, W. L., Oltmans, S. J., Chan, L. Y. and Harris, J. M. (1999). On springtime high ozone events in the lower troposphere from Southeast Asian biomass burning. Atmospheric Environment 33, pp. 2403-2410.

Ma, Y., Weber, R. J., Lee, Y. N., Orsini, D. A., Maxwell-Meier, K., Thornton, D. C., Bandy, A. R., Clarke, A. D., Blake, D. R., Sachse, G. W., Fuelberg, H. E., Kiley, C. M., Woo, J. H., Streets, D. G. and Carmichael, G. R. (2003a). Characteristics and influence of biosmoke on the fine-particle ionic composition measured in Asian outflow during the Transport and Chemical Evolution Over the Pacific (TRACE-P) experiment. J. Geophys. Res. 108, p. Doi: 10.1029/2002jd003128, doi: 10.1029/2002jd003128.

Ma, Y., Weber, R. J., Lee, Y. N., Orsini, D. A., Maxwell-Meier, K., Thornton, D. C., Bandy, A. R., Clarke, A. D., Blake, D. R., Sachse, G. W., Fuelberg, H. E., Kiley, C. M., Woo, J. H., Streets, D. G. and Carmichael, G. R. (2003b). Characteristics and influence of biosmoke on the fine-particle ionic composition measured in Asian outflow during the Transport and Chemical Evolution Over the Pacific (TRACE-P) experiment. J. Geophys. Res. 108, p. 8816, doi: 10.1029/2002jd003128.

Ma, Y., Hays, M. D., Geron, C. D., Walker, J. T. and Gichuru, M. J. G. (2010). Technical Note: Fast two-dimensional GC-MS with thermal extraction for anhydro-sugars in fine aerosols. Atmospheric Chemistry and Physics 10, pp. 4331-4341, doi: DOI 10.5194/acp-10-4331-2010.

Martinelli, L. A., Camargo, P. B., Lara, L. B. L. S., Victoria, R. L. and Artaxo, P. (2002). Stable carbon and nitrogen isotopic composition of bulk aerosol particles in a $\mathrm{C} 4$ plant landscape of southeast Brazil. Atmospheric Environment 36, pp. 2427-2432.

Morales, J. A., Pirela, D. and Durban, J. (1996). Determination of the levels of $\mathrm{Na}, \mathrm{K}, \mathrm{Ca}, \mathrm{Mg}$, $\mathrm{Fe}, \mathrm{Zn}$ and $\mathrm{Cu}$ in aerosols of the western Venezuelan savannah region. Science of the Total Environment 180, pp. 155-164. 
O'Malley, V. P., Burke, R. A. and Schlotzhauer, W. S. (1997). Using GCMS/Combustion/IRMS to determine the $13 \mathrm{C} / 12 \mathrm{C}$ ratios of individual hydrocarbons produced from the combustion of biomass materials--application to biomass burning. Organic Geochemistry 27, pp. 567-581.

Oliveira, C., Pio, C., Alves, C., Evtyugina, M., Santos, P., Goncalves, V., Nunes, T., Silvestre, A. J. D., Palmgren, F., Wahlin, P. and Harrad, S. (2007). Seasonal distribution of polar organic compounds in the urban atmosphere of two large cities from the North and South of Europe. Atmospheric Environment 41, pp. 5555-5570.

Oros, D. R., bin Abas, M. R., Omar, N. Y. M. J., Rahman, N. A. and Simoneit, B. R. T. (2006). Identification and emission factors of molecular tracers in organic aerosols from biomass burning: Part 3. Grasses. Applied Geochemistry 21, pp. 919-940, doi: DOI 10.1016/j.apgeochem.2006.01.008.

Otto, A., Gondokusumo, R. and Simpson, M. J. (2006). Characterization and quantification of biomarkers from biomass burning at a recent wildfire site in Northern Alberta, Canada. Applied Geochemistry 21, pp. 166-183.

Pashynska, V., Vermeylen, R., Vas, G., Maenhaut, W. and Claeys, M. (2002). Development of a gas chromatographic/ion trap mass spectrometric method for the determination of levoglucosan and saccharidic compounds in atmospheric aerosols. Application to urban aerosols. Journal of Mass Spectrometry 37, pp. 1249-1257.

Petterson, R. C. (1984). The chemical compostion of wood, In: Chemistry of solid wood, Rowell, R. (pp. 57-126), American Chemical Society, Washington, DC.

Pharham, R. A. and Gray, R. L. (1984). Formation and structure of wood, In: Chemistry of solid wood, Rowell, R. (pp. 3-56), American Chemical Society, Washington, DC.

Pio, C. A., Legrand, M., Alves, C. A., Oliveira, T., Afonso, J., Caseiro, A., Puxbaum, H., Sanchez-Ochoa, A. and Gelencser, A. (2008). Chemical composition of atmospheric aerosols during the 2003 summer intense forest fire period. Atmospheric Environment 42, pp. 7530-7543, doi: DOI 10.1016/j.atmosenv.2008.05.032.

Pochanart, P., Akimoto, H., Kajii, Y. and Sukasem, P. (2003). Carbon monoxide, regionalscale transport, and biomass burning in tropical continental Southeast Asia: Observations in rural Thailand. Journal of Geophysical Research 108, Doi: 10.1029/2002jd003360.

Puxbaum, H., Caseiro, A., Sanchez-Ochoa, A., Kasper-Giebl, A., Claeys, M., Gelencser, A., Legrand, M., Preunkert, S. and Pio, C. (2007). Levoglucosan levels at background sites in Europe for assessing the impact of biomass combustion on the European aerosol background. Journal of Geophysical Research-Atmospheres 112, Doi $10.1029 / 2006 j \mathrm{~d} 008114$.

Radojevic, M. (2003). Chemistry of forest fires and regional haze with emphasis on Southeast Asia. Pure and Applied Geophysics 160, pp. 157-187.

Ram, K. and Sarin, M. M. (2010). Spatio-temporal variability in atmospheric abundances of EC, OC and WSOC over Northern India. Journal of Aerosol Science 41, pp. 88-98, doi: DOI 10.1016/j.jaerosci.2009.11.004.

Roberts, A. F. (1970). A review of kinetics data for the pyrolysis of wood and related substances. Combustion and Flame 14, pp. 261-272.

Rudolph, J., Lowe, D. C., Martin, R. J. and Clarkson, T. S. (1997). A novel method for the compound specific determination of $\mathrm{d} 13 \mathrm{C}$ in volatile organic compounds at ppt levels in ambient air. Geophys. Res. Lett 24, pp. 659-662. 
Rudolph, J. (2007). Gas chromatography-isotope ratio mass spectrometry, In: Volatile Organic Compounds in the Atmosphere, Koppmann, R. (pp. 388-466), Blackwell Publisher, Oxford.

Sang, X. F., Chan, C. Y., Engling, G., Chan, L. Y., Wang, X. M., Zhang, Y. N., Shi, S., Zhang, Z. S., Zhang, T. and Hu, M. (2011). Levoglucosan enhancement in ambient aerosol during springtime transport events of biomass burning smoke to Southeast China. Tellus B 63, pp. 129-139, doi: 10.1111/j.1600-0889.2010.00515.x.

Schauer, J. J., Kleeman, M. J., Cass, G. R. and Simoneit, B. R. T. (2002). Measurement of emissions from air pollution sources. 4. C1-C27 organic compounds from cooking with seed oils. Environmental Science \& Technology 36, pp. 567-575.

Schkolnik, G., Falkovich, A. H., Rudich, Y., Maenhaut, W. and Artaxo, P. (2005). New Analytical Method for the Determination of Levoglucosan, Polyhydroxy Compounds, and 2-Methylerythritol and Its Application to Smoke and Rainwater Samples. Environmental Science \& Technology 39, pp. 2744-2752, doi: 10.1021/es048363c.

Schkolnik, G. and Rudich, Y. (2006). Detection and quantification of levoglucosan in atmospheric aerosols: a review. Analytical and Bioanalytical Chemistry 385, pp. 26-33, doi: 10.1007/s00216-005-0168-5.

Schmidl, C., Bauer, H., Dattler, A., Hitzenberger, R., Weissenboeck, G., Marr, I. L. and Puxbaum, H. (2008a). Chemical characterisation of particle emissions from burning leaves. Atmospheric Environment 42, pp. 9070-9079, doi: DOI 10.1016/j.atmosenv.2008.09.010.

Schmidl, C., Marr, L. L., Caseiro, A., Kotianova, P., Berner, A., Bauer, H., Kasper-Giebl, A. and Puxbaum, H. (2008b). Chemical characterisation of fine particle emissions from wood stove combustion of common woods growing in mid-European Alpine regions. Atmospheric Environment 42, pp. 126-141, doi: DOI 10.1016/j.atmosenv.2007.09.028.

Sergejewa, A. S., (1959). Chemie des holzes und der cellulose. Theodor Steinkopff Verlag, Dresden.

Shafizaden, F. (1984). The chemistry of pyrolysis and combustion, In: Chemistry of solid wood, Rowell, R. (pp. 489-529), American Chemical Society, Washington, DC.

Sheesley, R. J., Schauer, J. J., Chowdhury, Z., Cass, G. R. and Simoneit, B. R. T. (2003). Characterization of organic aerosols emitted from the combustion of biomass indigenous to South Asia. Journal of Geophysical Research 108, Doi: $10.1029 / 2002 j \mathrm{j} 002981$.

Simoneit, B. R. T., Schauer, J. J., Nolte, C. G., Oros, D. R., Elias, V. O., Fraser, M. P., Rogge, W. F. and Cass, G. R. (1999). Levoglucosan, a tracer for cellulose in biomass burning and atmospheric particles. Atmospheric Environment 33, pp. 173-182.

Simoneit, B. R. T., Kobayashi, M., Mochida, M., Kawamura, K., Lee, M., Lim, H. J., Turpin, B. J. and Komazaki, Y. (2004). Composition and major sources of organic compounds of aerosol particulate matter sampled during the ACE-Asia campaign. Journal of Geophysical Research 109, Doi 10.1029/2004jd004598.

Stohl, A., Forster, C., Huntrieser, H., Mannstein, H., McMillan, W. W., Petzold, A., Schlager, H. and Weinzierl, B. (2007). Aircraft measurements over Europe of an air pollution plume from Southeast Asia - aerosol and chemical characterization. Atmospheric Chemistry and Physics 7, pp. 913-937. 
Stott, P. (1988). The forest as Phoenix: towards a biogeography of fire in mainland South East Asia. The Geographical Journal 154, pp. 337-350.

Streets, D., Yarber, K., Woo, J. and Carmichael, G. (2003). Biomass burning in Asia: Annual and seasonal estimates and atmospheric emissions. Global Biogeochem. Cycles 17, p. 1099.

Thompson, A. M., Witte, J. C., Hudson, R. D., Guo, H., Herman, J. R. and Fujiwara, M. (2001). Tropical Tropospheric Ozone and Biomass Burning. Science 291, pp. 21282132, doi: 10.1126/science.291.5511.2128.

Venkataraman, C., Habib, G., Eiguren-Fernandez, A., Miguel, A. H. and Friedlander, S. K. (2005). Residential biofuels in south Asia: Carbonaceous aerosol emissions and climate impacts. Science 307, pp. 1454-1456, doi: DOI 10.1126/science.1104359.

Wan, E. C. H. and Yu, J. Z. (2006). Determination of sugar compounds in atmospheric aerosols by liquid chromatography combined with positive electrospray ionization mass spectrometry. Journal of Chromatography A 1107, pp. 175-181.

Wang, G. H., Kawamura, K., Xie, M. J., Hu, S. Y., Cao, J. J., An, Z. S., Waston, J. G. and Chow, J. C. (2009). Organic Molecular Compositions and Size Distributions of Chinese Summer and Autumn Aerosols from Nanjing: Characteristic Haze Event Caused by Wheat Straw Burning. Environmental Science \& Technology 43, pp. 64936499, doi: Doi 10.1021/Es803086g.

Wang, Q., Shao, M., Liu, Y., William, K., Paul, G., Li, X., Liu, Y. and Lu, S. (2007a). Impact of biomass burning on urban air quality estimated by organic tracers: Guangzhou and Beijing as cases. Atmospheric Environment 41, pp. 8380-8390.

Wang, S. H., Lin, N. H., Chou, M. D. and Woo, J. H. (2007b). Estimate of radiative forcing of Asian biomass-burning aerosols during the period of TRACE-P. Journal of Geophysical Research-Atmospheres 112, Doi: 10.1029/2006jd007564.

Wang, T., Wong, H. L. A., Tang, J., Ding, A., Wu, W. S. and Zhang, X. C. (2006). On the origin of surface ozone and reactive nitrogen observed at a remote mountain site in the northeastern Qinghai-Tibetan Plateau, western China. Journal of Geophysical Research 111, Doi: 10.1029/2005jd006527.

Ward, T. J., Hamilton, R. F., Dixon, R. W., Paulsen, M. and Simpson, C. D. (2006). Characterization and evaluation of smoke tracers in PM: Results from the 2003 Montana wildfire season. Atmospheric Environment 40, pp. 7005-7017, doi: DOI 10.1016/j.atmosenv.2006.06.034.

Xie, M., Wang, G., Hu, S., Gao, S., Han, Q., Xu, Y. and Feng, J. (2011). Polar organic and inorganic markers in PM10 aerosols from an inland city of China -- Seasonal trends and sources. Science of the Total Environment 408, pp. 5452-5460.

Yang, S., He, H., Lu, S., Chen, D. and Zhu, J. (2008). Quantification of crop residue burning in the field and its influence on ambient air quality in Suqian, China. Atmospheric Environment 42, pp. 1961-1969, doi.

Yttri, K. E., Dye, C. and Kiss, G. (2007). Ambient aerosol concentrations of sugars and sugaralcohols at four different sites in Norway. Atmospheric Chemistry and Physics 7, pp. 4267-4279.

Zdrahal, Z., Oliveira, J., Vermeylen, R., Claeys, M. and Maenhaut, W. (2002). Improved method for quantifying levoglucosan and related monosaccharide anhydrides in atmospheric aerosols and application to samples from urban and tropical locations. Environmental Science E Technology 36, pp. 747-753, doi: Doi 10.1021/Es015619v. 
Zhang, T., Claeys, M., Cachier, H., Dong, S., Wang, W., Maenhaut, W. and Liu, X. (2008). Identification and estimation of the biomass burning contribution to Beijing aerosol using levoglucosan as a molecular marker. Atmospheric Environment 42, pp. 70137021.

Zhang, Y. X., Shao, M., Zhang, Y.-h., Zeng, L.-m., He, L.-y., Zhu, B., Wei, Y.-j. and Zhu, X.-1. (2007). Source profiles of particulate organic matters emitted from cereal straw burnings. Journal of Environmental Sciences 19, pp. 167-175.

Zhang, Y. N., Zhang, Z. S., Chan, C. Y., Engling, G., Sang, X. F., Shi, S. and Wang, X. M. (2011). Levoglucosan and carbonaceous species in the background aerosol of coastal southeast China: case study on transport of biomass burning smoke from the Philippines. Environmental Science and Pollution Research (Accepted)

Zhang, Z., Engling, G., Lin, C. Y., Chou, C. C. K., Lung, S. C. C., Chang, S. Y., Fan, S., Chan, C. Y. and Zhang, Y. H. (2010). Chemical speciation, transport and contribution of biomass burning smoke to ambient aerosol in Guangzhou, a mega city of China. Atmospheric Environment 44, pp. 3187-3195. 


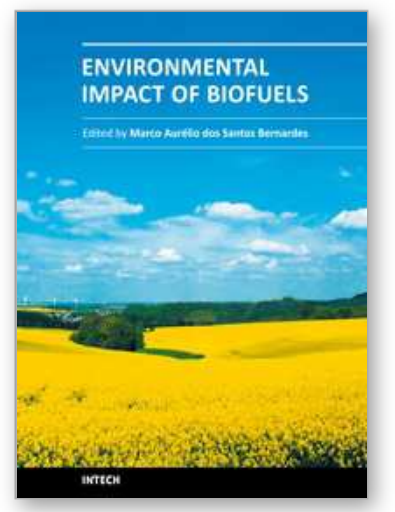

\author{
Environmental Impact of Biofuels \\ Edited by Dr. Marco Aurelio Dos Santos Bernardes
}

ISBN 978-953-307-479-5

Hard cover, 270 pages

Publisher InTech

Published online 06, September, 2011

Published in print edition September, 2011

This book aspires to be a comprehensive summary of current biofuels issues and thereby contribute to the understanding of this important topic. Readers will find themes including biofuels development efforts, their implications for the food industry, current and future biofuels crops, the successful Brazilian ethanol program, insights of the first, second, third and fourth biofuel generations, advanced biofuel production techniques, related waste treatment, emissions and environmental impacts, water consumption, produced allergens and toxins. Additionally, the biofuel policy discussion is expected to be continuing in the foreseeable future and the reading of the biofuels features dealt with in this book, are recommended for anyone interested in understanding this diverse and developing theme.

\title{
How to reference
}

In order to correctly reference this scholarly work, feel free to copy and paste the following:

Chuen-Yu Chan, Guenter Engling, Xuefang Sang and Ting Zhang (2011). Biofuel Combustion Emissions Chemical and Physical Smoke Properties, Environmental Impact of Biofuels, Dr. Marco Aurelio Dos Santos Bernardes (Ed.), ISBN: 978-953-307-479-5, InTech, Available from:

http://www.intechopen.com/books/environmental-impact-of-biofuels/biofuel-combustion-emissions-chemicaland-physical-smoke-properties

\section{INTECH}

open science | open minds

\author{
InTech Europe \\ University Campus STeP Ri \\ Slavka Krautzeka 83/A \\ 51000 Rijeka, Croatia \\ Phone: +385 (51) 770447 \\ Fax: +385 (51) 686166 \\ www.intechopen.com
}

\author{
InTech China \\ Unit 405, Office Block, Hotel Equatorial Shanghai \\ No.65, Yan An Road (West), Shanghai, 200040, China \\ 中国上海市延安西路65号上海国际贵都大饭店办公楼 405 单元 \\ Phone: +86-21-62489820 \\ Fax: +86-21-62489821
}


(C) 2011 The Author(s). Licensee IntechOpen. This chapter is distributed under the terms of the Creative Commons Attribution-NonCommercialShareAlike-3.0 License, which permits use, distribution and reproduction for non-commercial purposes, provided the original is properly cited and derivative works building on this content are distributed under the same license. 